\title{
Termometry szklane cieczowe - charakterystyka przyrządów
}

\section{Liquid-in-Glass Thermometers - characteristics of instruments}

\author{
Jacek Matusik \\ Instytut Nafty i Gazu - Państwowy Instytut Badawczy
}

\begin{abstract}
STRESZCZENIE: W artykule przedstawiono charakterystykę termometrów szklanych cieczowych. Przyrządy te pomimo swojej wielowiekowej historii i stosunkowo prostej konstrukcji pod względem dokładności i stabilności pomiarów nie odbiegają od platynowych czujników termorezystancyjnych. Natomiast zalety, takie jak na przykład brak konieczności zasilania elektrycznego sprawiają, że niejednokrotnie są one najlepszym lub jedynym możliwym rozwiązaniem (na przykład pomiar temperatury otoczenia w atmosferze wybuchowej lub pomiar temperatury cieczy łatwopalnych). Warunkiem otrzymywania prawidłowych wyników pomiarów jest posiadanie wiedzy na temat zasady działania termometrów szklanych cieczowych oraz właściwego sposobu korzystania z tych przyrządów. W artykule opisano budowę i zasadę działania tych przyrządów. Wskazano różnice konstrukcyjne w poszczególnych typach termometrów. Określono czym należy się kierować przy doborze odpowiedniego termometru do danego zastosowania. W szczególności zwrócono uwagę na aspekty mające istotny wpływ na precyzję pomiarów, takie jak: typ termometru, głębokość zanurzenia nominalnego, rodzaj zastosowanej cieczy oraz klasę dokładności i wielkość działki elementarnej. Omówiono również metodykę prawidłowego wykonywania pomiarów. Zwrócono uwagę na takie aspekty i problemy, jak: poprawna pozycja pracy i głębokość zanurzenia termometru, błąd paralaksy, zjawisko ospałości i histerezy, występowanie menisków i prawidłowy odczyt wskazania. Zaakcentowano konieczność wykonywania dokładnych oględzin termometru przed każdym użyciem. Czynność ta ma zapobiec ryzyku uzyskania nieprawidłowych odczytów, gdyż często pozornie niewielki defekt czy uszkodzenie przyrządu może mieć bardzo istotny wpływ na wynik pomiaru wykonany za pomocą tych przyrządów. Omówiono sposób wykonywania oględzin, oraz przedstawiono fotografie obrazujące typowe dla tych przyrządów uszkodzenia. W treści artykułu omówiony został również prawidłowy sposób magazynowania, transportu oraz nadzoru nad tymi przyrządami. Podano zalecany dla tych przyrządów czasookres wzorcowań i sprawdzeń okresowych.
\end{abstract}

Słowa kluczowe: termometr szklany cieczowy, termometr rtęciowy, termometr, wzorcowanie.

ABSTRACT: The article presents the characteristics of liquid glass thermometers. These instruments, despite their centuries-old history and relatively simple design in terms of accuracy and stability of measurements, do not differ from platinum resistance thermometers. On the other hand, advantages such as the lack of the need for electric power supply often make them the best or only possible solution (for example, the measurement of the ambient temperature in an explosive atmosphere or temperature measurement of flammable liquids). The condition, however, to obtain the correct measurement results is to have knowledge about the principle of operation of liquid glass thermometers, and the correct way of using these instruments. The article describes the construction and operation of these devices. Design differences in particular types of thermometers are indicated. It indicates what should be followed when choosing the right thermometer for a given application. In particular, attention was paid to aspects having a significant impact on the precision of measurements, such as the type of thermometer, the depth of nominal draft, the type of liquid used, and the class of accuracy and size of the elementary plot. Of course, the methodology of correct measurements was also discussed. Attention was paid to aspects and problems such as the correct position of work and immersion depth of the thermometer, parallax error, phenomenon of lethargy and hysteresis, occurrence of meniscus, and correct reading of the indication. The need to perform an accurate visual inspection of the thermometer before each use was indicated. This step is to prevent the risk of incorrect readings, because often a seemingly small defect or damage to the device can have a very significant effect on the measurement result made using these instruments. The method of inspection are discussed, and photographs showing typical damage to these devices are presented. The article also discusses the correct method of storage, transport and supervision of these devices. The time of calibration and periodic checking recommended for these instruments is provided.

Key words: liquid-in-glass thermometer, mercury thermometer, thermometer, calibration.

Autor do korespondencji: J. Matusik, e-mail: jacek.matusik@inig.pl

Artykuł nadesłano do Redakcji 19.03.2019 r. Zatwierdzono do druku 6.06.2019 r. 


\section{Wprowadzenie}

Pomimo tego, że pierwszy termometr cieczowy wynaleziono już kilka stuleci temu, przyrządy te wciąż pozostają jednymi z najdokładniejszych przyrządów służących do pomiaru temperatury. Termometry szklane cieczowe pomimo prostoty swojej konstrukcji, jeżeli są wykonane poprawnie, pod względem dokładności i stabilności pomiarów mogą konkurować z platynowymi czujnikami termorezystancyjnymi (Bakoń, 2009) (Tyszownicka i Jaworski, 2010). Warunkiem jednak otrzymywania prawidłowych wyników pomiarów jest wiedza na temat zasady działania termometrów szklanych cieczowych oraz właściwego sposobu korzystania z tych przyrządów.

\section{Konstrukcja przyrządów}

Termometry cieczowe wykorzystują zależność zmiany objętości cieczy termometrycznej od zmian temperatury. Zasadniczą część termometru stanowi wykonany ze szkła zbiorniczek wypełniony cieczą termometryczną połączony z kapilarą zaopatrzoną w podziałkę. Pod względem konstrukcyjnym termometry dzielą się na pałeczkowe (bagietkowe) oraz rurkowe. Te pierwsze wykonane są z pręta szklanego z osiowo umieszczonym w nim kanałem kapilary. Podziałka jest naniesiona na powierzchni pręta. W termometrach rurkowych słupek kapilarny i obudowa termometru stanowią dwie oddzielne części, zespolone ze sobą jedynie u ujścia zbiornika. W obudowie znajduje się również przytwierdzona do słupka skala naniesiona na płytce z mlecznego szkła. Na rysunku 1 przedstawiono termometr szklany cieczowy w wykonaniu rurkowym (rys. 1a) oraz pałeczkowym (rys. 1b).

W konstrukcji przyrządu wyróżnić można następujące elementy (Knake, 2018):

- zbiornik - jest to zasadnicza część czuła termometru. Objętość zbiornika zaprojektowana jest tak, aby przy uwzględnieniu rozszerzalności cieplnej cieczy wystarczyło jej do osiągnięcia maksimum głównej podziałki przyrządu;

- ujście lejkowe zbiornika - łączy słupek ze zbiornikiem;

- podziałka pomocnicza - dodatkowa skala nie występująca we wszystkich termometrach, najczęściej wyskalowana do punktu $0^{\circ} \mathrm{C}$, gdy nie obejmuje go główny zakres termometru. Stosowana

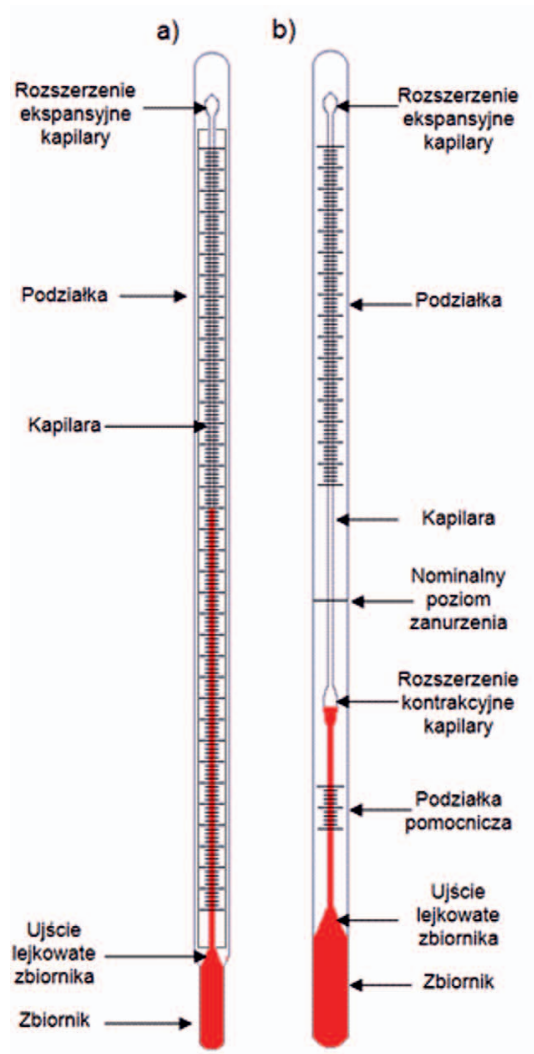

Rys. 1. Konstrukcja termometru szklanego cieczowego

Fig. 1. Construction of a liquid glass thermometer może być w celu okresowego sprawdzania poprawności wskazań przyrządu;

- rozszerzenie kontrakcyjne kapilary - występuje wtedy, gdy jest potrzeba skrócenia całkowitej długości słupka cieczy potrzebnej do osiągnięcia poziomu głównej skali;

- menisk - górna granica cieczy zakończona jest meniskiem, którego kształt zależy od rodzaju zastosowanej cieczy. Dla cieczy niezwilżających menisk ma kształt wypukły, dla cieczy zwilżających wklęsły;

- nominalny poziom zanurzenia - wskazanie określonego poziomu zanurzenia nanoszone jest na termometr, oczywiście tylko w przypadku termometrów z nominalnym zanurzeniem częściowym;

- $\quad$ kapilara - część kapilary powyżej poziomu cieczy często wypełniana jest gazem obojętnym takim, jak azot, aby zapobiec rozdzielaniu się słupka cieczy lub jej odparowaniu; - podziałka główna;

- rozszerzenie ekspansyjne kapilary - rozszerzenie nazywane również komorą rozprężną. Zapobiega ono wzrostowi ciśnienia, gdy temperatura cieczy przekroczy górną granicę skali. Objętość komory jest zaprojektowana tak, aby w razie konieczności zdolna była pomieścić potrzebną ilość cieczy.

Do budowy termometrów powinno stosować się szkło posiadające możliwie jak najmniejszą rozszerzalność objętościową i histerezę cieplną. Z kolei dobra ciecz termometryczna powinna cechować się stałym, w możliwie szerokim zakresie temperatur, współczynnikiem rozszerzalności, wyraźnym meniskiem, brakiem zwilżania ścianek, niską temperaturą zamarzania i wysoką temperaturą wrzenia. Powyższe wymagania doskonale spełnia rtęć, jednakże z uwagi na jej toksyczność, od ponad 20 lat prowadzona jest szeroko zakrojona światowa polityka ograniczania emisji rtęci do różnych elementów środowiska naturalnego (Król et al., 2016), czego efektem jest przyjęta w 2007 roku przez Parlament Europejski dyrektywa zabraniająca jej stosowania w termometrach przeznaczonych do otwartej sprzedaży. Wciąż można je jednak zakupić do zastosowań laboratoryjnych. Oprócz samej rtęci w termometrach stosuje się również amalgamaty rtęci oraz różnego rodzaju ciecze organiczne takie, jak alkohol, toluen i pentan. Ciecze organiczne cechują się jednak istotnymi wadami (Sobieski, 2015): 
- zwilżające właściwości w stosunku do szkła, co powoduje wklęsły menisk cieczy (i w konsekwencji trudności $\mathrm{w}$ ustaleniu poziomu cieczy w kapilarze) oraz pozostawanie cieczy na ściance kapilary, powodujące obniżenie poziomu słupka cieczy;

- bezbarwność, co stwarza konieczność ich zabarwiania. Stosowane barwniki starzeją się i osadzają na dnie zbiornika, co wpływa na dokładność pomiarów;

- parowanie cieczy przy grzaniu, co stwarza możliwość skraplania par w chłodniejszych obszarach;

- złe przewodnictwo cieplne, co wpływa na zwiększenie bezwładności wskazań termometru.

W tabeli 1 zebrano zalety oraz wady termometrów szklanych cieczowych. W dalszej części artykułu przedstawiono szereg zaleceń, których należy przestrzegać przy korzystaniu z termometrów szklanych cieczowych. Stosowanie się do tych zasad zwiększy pewność, że uzyskiwane wyniki pomiarów będą obarczone jak najmniejszym błędem.

Tabela 1. Zalety i wady termometrów szklanych cieczowych

Table 1. Adventages and disadventages of liquid glass thermometers

\begin{tabular}{|l|}
\hline Zalety termometrów szklanych cieczowych \\
\hline - zarówno do pomiarów, jak i wskazań odczytów temperatury - ter- \\
mometry te nie wykorzystują zjawisk elektrycznych (możliwość \\
stosowania w strefach zagrożonych wybuchem); \\
- powtarzalność wykonania; \\
- łatwe w użyciu; \\
- tanie. \\
\hline Wady termometrów szklanych cieczowych \\
\hline - uzyskiwanie wiarygodnych wyników pomiarów wymaga od użyt- \\
kownika wprawy i doświadczenia; \\
- odczyt wskazania temperatury wymaga bezpośredniego kontaktu \\
wzrokowego z przyrządem, bądź zastosowania do odczytu urzą- \\
dzenia elektronicznego rejestrującego obraz; \\
- stosowana wciąż w termometrach laboratoryjnych rtęć jest wyso- \\
ce toksyczna.
\end{tabular}

\section{Właściwy dobór termometru}

Wybór właściwego dla danego zastosowania termometru szklanego cieczowego powinien nastąpić po rozważeniu kilku istotnych kwestii związanych z pomiarem. Przede wszystkim należy wybrać termometr o odpowiednim zakresie pomiarowym oraz klasie dokładności. Dokument OIML R 133 definiuje sześć klas, od $\mathrm{A}\left(\mathrm{MPE}= \pm 0,1^{\circ} \mathrm{C}\right)$ do $\mathrm{F}\left(\mathrm{MPE}= \pm 5,0^{\circ} \mathrm{C}\right)$. Istotny wpływ na dokładność pomiarów ma również rodzaj zanurzenia nominalnego. Pierwszą grupą są przyrządy z zanurzeniem nominalnym częściowym (partial immersion). W tym przypadku termometr zawsze, bez względu na wartość mierzonej temperatury, powinien być zanurzony w medium na stałej głębokości, określonej i oznaczonej przez producenta na obudowie. Z uwagi na to, że wystająca część słupka cieczy narażona jest na zmienną temperaturę otoczenia, ten typ termometrów dedykowany jest raczej do mniej dokładnych pomiarów. Inna grupa to termometry z zanurzeniem nominalnym całkowitym (total immersion). W tym przypadku głębokość zanurzenia wyznacza górna granica słupka cieczy. Jest to najczęściej spotykany w laboratoriach typ termometrów. Ostatnia grupa to termometry z zanurzeniem nominalnym zupełnym (complete immersion), gdzie właściwym poziomem zanurzenia jest zanurzenie całego termometru w medium. $\mathrm{Z}$ uwagi na konieczność wynurzania tego typu termometru $\mathrm{z}$ medium w celu odczytu, stosuje się je z reguły tylko do pomiaru temperatury powietrza w obiektach lub cieczy w przezroczystych zbiornikach.

\section{Transport i przechowywanie}

Termometry szklane cieczowe są najdelikatniejszymi spośród wszystkich przyrządów służących do pomiaru temperatury. Stąd też należy zwrócić szczególną uwagę na sposób ich transportu. Nieostrożne przemieszczanie termometru może skutkować rozdzieleniem się słupka cieczy lub w skrajnym przypadku rozbiciem się delikatnej szklanej konstrukcji przyrządu. Najważniejszą zasadą jest to, aby w transporcie przyrząd zawsze znajdował się w pozycji pionowej. W przypadku konieczności wysłania termometru poza laboratorium, należy zabezpieczyć go odpowiednim opakowaniem przed wstrząsami oraz przewróceniem. Przyrząd należy transportować osobiście lub za pośrednictwem zaufanych osób. Niedopuszczalne jest w tym przypadku korzystanie z firm kurierskich.

Podczas magazynowania, podobnie jak w transporcie, przyrząd również powinien znajdować się w pozycji pionowej. Takie przechowywanie pozwala skorzystać z przyrządu w każdej chwili. W przypadku, gdy przyrząd znajdował się w innej pozycji, przed wykonaniem pomiarów musi on odstać w pionie przynajmniej przez trzy kolejne doby.

\section{Wzorcowanie i sprawdzanie okresowe}

Dla zapewnienia wiarygodności pomiarów każdy przyrząd pomiarowy musi zostać poddany procesowi wzorcowania i w chwili pomiaru posiadać aktualne świadectwo wzorcowania. Liczba punktów wzorcowania termometru szklanego cieczowego zależy od jego zastosowania. Jeśli jest on przeznaczony do ogólnego użytku w całym swoim zakresie pomiarowym, to należy wybrać co najmniej trzy punkty w celu uzyskania krzywej poprawki. Punkty pośrednie można interpolować. Jednakże jeśli termometr przeznaczony jest do monitorowania konkretnych wartości temperatur, to punkty muszą 
być dobrane tak, aby w obrębie każdej spodziewanej w procesie temperatury wybrany był przynajmniej jeden punkt wzorcowania. Jeśli jest to tylko jeden punkt, zaleca się aby dobrać w jego obrębie dwa kolejne w celu sprawdzenia zmian wskazań przyrządu w obrębie tego punktu. Niezwykle istotne jest to, aby pośród wybranych punktów znajdował się również punkt $0^{\circ} \mathrm{C}$, który posłuży potem do sprawdzeń okresowych przyrządu i monitorowania jego dryfu.

Częstotliwość wzorcowania termometrów szklanych cieczowych zależy od wielu czynników. Jeśli użytkownik na podstawie historii przyrządu stwierdza, że przyrząd cechuje się dobrą stabilnością wskazań, czasookres wzorcowań może wynosić od roku do nawet pięciu lat. Jednakże jeśli termometr jest nowy, posiada dokładną skalę lub służy do monitorowania bardzo ważnych procesów powinien on być wzorcowany częściej. Dodatkowym czynnikiem wpływającym na czasookres wzorcowania jest to w jakich warunkach termometr jest przechowywany i jakim czynnikom jest poddawany w trakcie pracy. Wysoka temperatura (powyżej $200^{\circ} \mathrm{C}$ ), uderzenia i drgania mogą powodować degradację cieczy lub inne uszkodzenia w konstrukcji termometru. Niektóre nieprawidłowości mogą nie zostać dostrzeżone poprzez oględziny termometru, dlatego dla zapewnienia wiarygodności pomiarów bardzo ważne oprócz wzorcowania jest również okresowe sprawdzanie termometru w punkcie zerowym. Sprawdzenie takie, jeśli to tylko możliwe należy wykonywać przed każdym użyciem przyrządu lub jeśli jest on w ciągłym użyciu to co dwa miesiące. Polega ono na umieszczeniu termometru w mieszaninie wody z lodem (tzw. punkt topnienia lodu) i porównaniu wskazań z wartością odczytaną z aktualnego świadectwa wzorcowania. Jeśli wartości się od siebie nieznacznie różnią dopuszcza się przesunięcie wszystkich wartości poprawek ze świadectwa o wartość wyznaczoną przy sprawdzeniu w punkcie $0^{\circ} \mathrm{C}$. Jednakże jeśli przesunięcie jest znaczne lub jeśli zależy nam na dokładności pomiarów, przyrząd taki należy oddać do ponownego wzorcowania.

\section{Oględziny termometru}

Niewłaściwy transport, przechowywanie lub szereg innych czynników może być przyczyną wystąpienia w termometrze szklanym cieczowym różnego rodzaju defektów, mających istotny wpływ na dokładność przyrządu. Stąd też przed każdym użyciem termometr szklany powinien zostać poddany oględzinom w przynajmniej dziesięciokrotnym powiększeniu. W pierwszej kolejności należy zwrócić uwagę na to, czy przyrząd nie nosi śladów uszkodzeń mechanicznych oraz czy podziałka nie przemieszcza się względem kapilary. W dalszej kolejności należy skontrolować ciągłość słupka cieczy w kapilarze (fot. 1 i 2) oraz ewentualne rozdzielenie się cieczy i obecność niewielkich kropelek w zbiorniku ekspansyjnym. Czasami w przypadku cieczy organicznych na ściankach zbiornika ekspansyjnego obserwowana jest kondensacja. W przypadku rozdzielenia się słupka, można podjąć czynności (np. ogrzewanie, schładzanie, wytrząsanie) mające na celu jego ponowne połączenie (OIML R 133:2002). Zawsze jednak po takiej czynności należy oddać przyrząd do wzorcowania. W przypadku kondensacji należy zastosować termometr z cieczą innego rodzaju. Jeśli w kapilarze lub zbiorniku zaobserwowane zostaną różnego rodzaju ciała stałe (np. drobinki szkła), termometr taki należy wycofać z eksploatacji. Do rzadkości należą zjawiska związane z degradacją cieczy termometrycznej, jednak należy mieć je również na uwadze. Jeśli w termometrze zaobserwuje się zmianę barwy cieczy lub jakiekolwiek produkty uboczne utleniania lub rozkładu cieczy w kapilarze lub zbiorniku (fot. 3), również należy niezwłocznie wycofać go z eksploatacji (Cross et al., 2009).

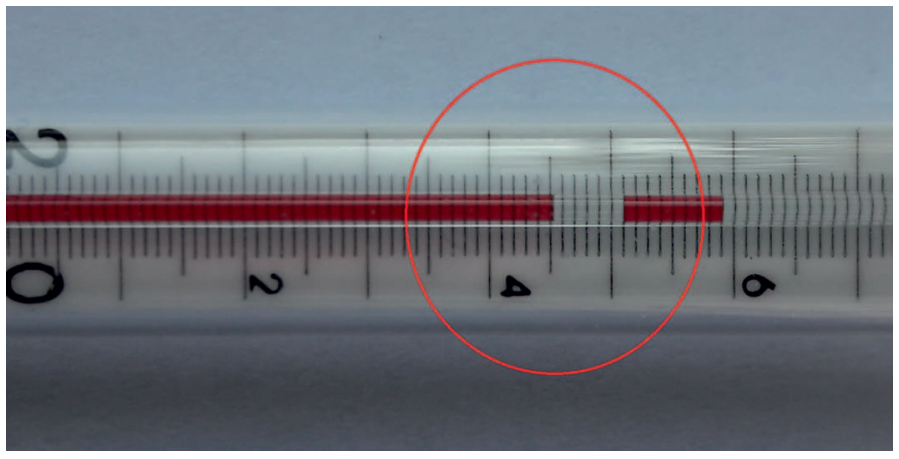

Fot. 1. Termometr szklany cieczowy - rozdzielony słupek cieczy Photo 1. Liquid glass thermometer - separated liquid column

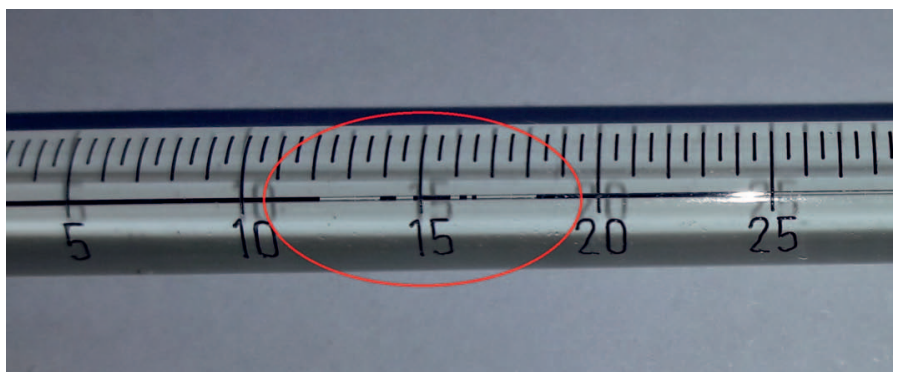

Fot. 2. Termometr szklany cieczowy - rozdzielony słupek cieczy

Photo 2. Liquid glass thermometer - separated liquid column

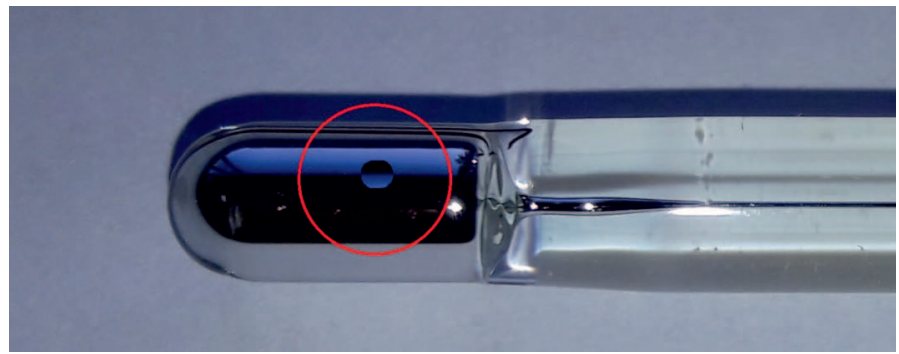

Fot. 3. Termometr szklany cieczowy - defekt w zbiorniku

Photo 3. Liquid glass thermometer - defect in the bulb 


\section{Wykonywanie pomiarów}

Właściwą i jedyną pozycją pracy termometru szklanego cieczowego jest pozycja pionowa, zbiornikiem skierowanym ku dołowi. Jeżeli wymuszenie takiej pozycji nie jest możliwe należy zastosować czujnik temperatury innego rodzaju.

Przy umieszczaniu termometru w medium należy zachować ostrożność i w przypadku dużych różnic temperatur zanurzać przyrząd powoli. Zbyt szybkie nagrzewanie termometru może spowodować wytworzenie się w obrębie cieczy termometrycznej pęcherzyków gazu, a z kolei zbyt szybkie chłodzenie może prowadzić do problemów z odprowadzaniem cieczy.

Przed przystąpieniem do wykonywania odczytów wskazań termometru należy upewnić się, że w układzie pomiarowym nastąpiła stabilizacja, tzn. czy słupek cieczy zatrzymał się na stałym poziomie. Należy mieć na uwadze to, że szkło stosunkowo szybko zwiększa swoją objętość pod wpływem ciepła, ale znacznie wolniej zmniejsza ją przy spadku temperatury. W przypadkach bardzo precyzyjnych termometrów szklanych po ich podgrzaniu podczas pomiaru wysokich temperatur konieczne jest odczekanie nawet kilku dni aż termometr powróci do swojej pierwotnej formy (Rogala, 2014).

Kolejną kwestią, której należy bezwzględnie przestrzegać to poziom zanurzenia nominalnego określony przez producenta. Każde inne zanurzenie wnosi do pomiaru błąd związany z tym, że część słupka cieczy termometrycznej znajduje się w temperaturze innej niż powinno znajdować się przy poprawnej konfiguracji, co znacząco wpływa na zaniżenie lub zawyżenie wskazania termometru. W pewnych przypadkach można zastosować odstępstwo od tej zasady, jednakże należy wtedy zastosować dodatkowy termometr w celu wyznaczenia poprawki na wystający słupek cieczy termometrycznej. Poprawkę tą wyznacza się zgodnie ze wzorem (1):

$$
K_{f}=\gamma \cdot n \cdot\left(t_{s}-t^{\prime}\right)
$$

gdzie:

$\gamma$ - współczynnik pozornej rozszerzalności cieczy termometrycznej,

$n$ - liczba stopni Celsjusza odpowiadająca długości wystającego słupka cieczy,

$t_{s}$ - temperatura pomiaru $\left[{ }^{\circ} \mathrm{C}\right]$,

$t^{\prime}$ - średnia temperatura wystającego słupka cieczy $\left[{ }^{\circ} \mathrm{C}\right]$.

Zjawiskiem, które ma największy wpływ na poprawność pomiarów przy korzystaniu z omawianych przyrządów jest błąd paralaksy. Ma on zmienny charakter, ponieważ w dużej mierze zależy od umiejętności i doświadczenia wykonującego pomiary. Związany jest on ze zjawiskiem załamania promienia światła. Nie występuje ono, gdy odczytu dokonuje się dokładnie pod kątem prostym do osi termometru i narasta wraz ze zmianą kąta patrzenia. Doświadczenie i ostrożność podczas wykonywania pomiarów pozwala zminimalizować wpływ tego błędu do minimum (Srivastava, 2008).

Dokładność termometrów szklanych cieczowych pozwala na odczyt wskazań z precyzją większą niż działka elementarna. Poprzez zastosowanie szkła powiększającego działkę elementarną można podzielić na dziesięć części. Zakończenie słupka cieczy charakteryzuje się występowaniem menisku, który dla cieczy zwilżających (np. alkohol) ma kształt wklęsły, a dla niezwilżających (np. rtęć) kształt wypukły. Wartość temperatury wskazywaną przez termometr określa najwyższy punkt menisku.

\section{Podsumowanie}

Wykonywanie pomiarów za pomocą termometrów szklanych cieczowych zawsze narażone jest na wystąpienie błędów. Związane są one z licznymi procesami stosowanymi przy wytwarzaniu termometrów, przy ich wzorcowaniu oraz przy wykonywaniu pomiarów. Chociaż większość błędów ma stosunkowo mały wpływ na wynik pomiarów, to jednak ich kumulacja może znacząco zakłócić odczyt za pomocą tych przyrządów, od których niejednokrotnie oczekuje się dużych dokładności. Można się przed tym jednak skutecznie ustrzec poprzez poznanie przyczyn występowania niekorzystnych zjawisk oraz stosowanie się do zasad poprawnego korzystania z tych przyrządów. Celem, który przyświecał autorowi niniejszego artykułu było przybliżenie wszystkich istotnych kwestii związanych z termometrami szklanymi cieczowymi, których przestrzeganie pozwoli użytkownikom na wykonywanie wiarygodnych pomiarów.

\section{Literatura}

Bakoń T., 2009. Czynniki wpływające na częstość wzorcowań przyrządów do pomiaru temperatury, wilgotności i ciśnienia. PAKGOŚ, tom 4.

Cross C.D., Miller W.W., Ripple D.C., Strouse G.F., 2009. Maintenance, Validation, and Recalibration of Liquid-in-Glass Thermometers. National Institute of Standards and Technology Special Publication 1088.

Knake M., 2011. The Anatomy of a Liquid-in-Glass Thermometer. http:// www.aashtoresource.org (dostęp: 22.11.2018).

Król A., Kukulska-Zając E., Macuda J., 2016. Metody monitoringu i remediacji gruntów zanieczyszczonych rtęcią na terenach przemysłowych. Nafta-Gaz, 8: 626-631. DOI: 10.18668/NG.2016.08.06.

OIML R133:2002 Liquid-in-glass thermometers.

Rogala D., 2014. System do bezkontaktowego pomiaru temperatury ciała człowieka. Praca magisterska. Politechnika Warszawska.

Sobieski W., 2015. Termodynamika w eksperymentach. Uniwersytet Warmińsko-Mazurski, Olsztyn.

Srivastava G.P., 2008. Surface Meteorological Instruments and Measurement Practices. Atlantic Publishers and Distributors (P) Ltd.

Tyszownicka M., Jaworski J., 2010. Nowe podejście do kontroli metrologicznej przeliczników, w świetle wymagań dyrektywy MID. Nafta-Gaz, 12: $1138-1143$.

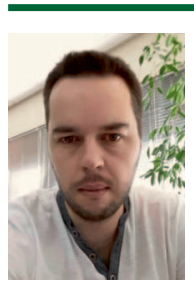

Mgr inż. Jacek MATUSIK

Specjalista inżynieryjno-techniczny;

Zastępca kierownika Laboratorium Wzorcującego,

Zakład Metrologii Przepływów

Instytut Nafty i Gazu - Państwowy Instytut Badawczy

ul. Lubicz 25 A, 31-503 Kraków

E-mail: jacek.matusik@inig.pl 